\title{
A NECESSIDADE DE COMPATIBILIZAÇÃO DA COISA JULGADA NAS AÇÕES COLETIVAS: CONTRIBUIÇÃO DO NOVO CPC
}

\section{THE NECESSARY COMPATIBILITY OF THE RES JUDICATA IN THE CLASS ACTION: CONTRIBUTION OF THE NEW CIVIL PROCEDURE CODE}

ELAINE HARZHEIm MACEDO

Doutora e Mestre em Direito, Especialista em direito processual civil, Professora na Graduação e no Programa de PósGraduação em Direito junto à PUCRS. Desembargadora aposentada do Tribunal de Justiça do Rio Grande do Sul. ExPresidente do Tribunal Regional Eleitoral do Rio Grande do Sul. Membro do Instituto dos Advogados do Rio Grande do Sul. Presidente do IGADE - Instituto Gaúcho de Direito Eleitoral. Advogada. elaine@fhm.adv.br

LEANDRO PAMPLONA Mestre e doutorando em Direito pela PUC-RS. Professor da graduação e pós da UNISC. Professor convidado do PósGraduação em Direito Processual Civil da FEEVALE, IMED e ESA. Advogado pamplona@dvogadors.com.br

\section{RESUMO}

A coisa julgada, direito fundamental garantido no art. $5^{\circ}$, inciso XXXVI, da Constituição republicana, foi construída ao longo dos séculos para servir ao processo subjetivo individual com vista ao dogma da segurança jurídica, não perdendo sua contemporaneidade porque os conflitos individuais continuam presentes na sociedade, clamando pela intervenção do Poder Judiciário. Contudo, o fenômeno dos conflitos coletivos e dos conflitos repetitivos, produto de uma sociedade em que 0 individual cede espaço ao coletivo, passa a exigir do Estado novos enfrentamentos, através de suas funções legislativa e jurisdicional. Temas como efeitos negativos e positivos, limites subjetivos e objetivos da coisa julgada reclamam compatibilização nas ações coletivas. O novo CPC, voltado para a composição do conflito subjetivo individual, adentra nesta seara, especialmente ao regular as ações pseudoindividuais, que têm por fundamento conflitos coletivos ou conflitos individuais homogêneos, estabelecendo uma ponte de comunicação entre o processo civil individual e o coletivo.

Palavras-chave: coisa julgada; processo coletivo; conflitos individuais; conflitos coletivos; conflitos repetitivos; novo CPC.

\begin{abstract}
The res judicata is a fundamental right guaranteed by the art. $5^{\circ}, \mathrm{XXXVI}$ of the Republican Constitution. It was built over de centuries to serve the individual demands as a legal safety and still important as long as conflicts exist needing the court to interview. However, the class actions and repetitive actions require a new State's position in terms of jurisdiction and legislation. The new Civil Procedure Code is focus on the settlement between the litigants. Therefore it define demands that aren't completely individual since the claim's fundamental is a class actions or civil actions based in homogeneous individual rights. Thus, occur a bond amongst the civil action and the class action.
\end{abstract}

Keywords: res judicata; class action; civil action; new Civil Procedure Code 


\section{SUMÁRIO}

INTRODUÇAO; 1 ASPECTOS GERAS SOBRE A COISA JULGADA; 1.1 Coisa julgada como direito fundamental; 1.2 Coisa julgada formal e material; 1.3 Função negativa e positiva da coisa julgada; 1.4 Limites subjetivos e objetivos da coisa julgada; 2 A CONCEPÇÃO CLÁSSICA DA COISA JULGADA E 0 FENÔMENO DAS AÇÕES COLETIVAS: DISTANCIAMENTO E APROXIMAÇÕES; 2.1 Direitos coletivos e defesa coletiva de direitos; 2.2 Coisa julgada nas ações coletivas; 3 CONTRIBUTO DO NOVO CPC E OS CONFLITOS REPETITIVOS. CONCLUSÃO; REFERÊNCIAS.

\section{INTRODUÇÃO}

Com o advento do novo Código de Processo Civil diversas dúvidas inquietam a comunidade jurídica. A questão basilar é a melhora ou não do sistema atual. 0 presente estudo tem como desiderato analisar as novidades envolvendo a coisa julgada, construída sob ideais individuais, e a previsão de regulação de ações pseudoindividuais no novo CPC. Para tanto foi utilizado método de procedimento histórico com pesquisa bibliográfica investigando-se as raízes do instituto no nosso sistema jurídico e sua evolução. Em virtude da análise da evolução do processo individual para o coletivo e o respectivo impacto na coisa julgada o método de abordagem será o dialético, estabelecendo-se pontos e contrapontos quanto à nova legislação processual, sendo ainda insuficiente bibliografia específica frente a sua contemporaneidade.

A cultura jurídica romano-germânica, sistema ou família ${ }^{1}$, da qual descendemos, mas com forte predominância, na área do processo civil, da vertente romano-canônica, foi se desenvolvendo com base em direitos materiais e processuais subjetivos. Os conflitos existentes envolviam particulares, entre si, ou particulares e o Estado, mas sem abdicar da ideia do conflito de interesses subjetivos, interesses esses a ser objeto de proteção da lei ou do juiz. Da mesma forma, a jurisdição, embora constituída a partir da constituição do Estado liberal como poder ou função pública, possuía eminentemente um caráter privado acentuado a partir de sua função primordial: compor os conflitos.

Num primeiro momento, na origem desse movimento histórico, cabia aos pontífices o julgamento dos litígios de natureza privada. A aparição de um terceiro imparcial, juiz ou árbitro, em verdade, tinha função muito mais sancionadora ou ratificadora de um exercício privado do

${ }^{1}$ DAVID, René. Os grandes sistemas do Direito contemporâneo. São Paulo: Martins Fontes, 2002. 
direito $^{2}$. Nessa época os conflitos decorriam, na maioria, de direitos de propriedade, possessórios e obrigacionais.

0 processo civil romano antigo pode ser dividido em três grandes períodos: legis actiones, formulário e da cognitio extra ordinem, correspondendo a três grandes momentos do Império Romano ${ }^{3}$. 0 período formulário do ordo iudiciorum privatorum, considerado o procedimento comum da era medieval ${ }^{4}$, era reservado ao tratamento de relações obrigacionais privadas, no qual um juiz igualmente privado escolhido pelas partes (iudex), não dispunha de império, limitando-se à função declaratória ${ }^{5}$.

Apenas no período da cognitio extra ordinem deu-se início à oficialização da jurisdição, com a existência de magistrados funcionários do império romano, considerado como período pósclássico. Com efeito, os últimos dois períodos preservaram as características da primeira fase, conservando o carácter privado da jurisdição ${ }^{6}$.

A cultura romana, porém, foi vilipendiada, reformada, revistada e reconstruída por influências e novos valores culturais, no período medieval e face à invasão dos povos bárbaros, especialmente da tradição germânica, sem embargo, paralelamente, de o mesmo movimento de transformação do direito romano ter sido levado a efeito pela influência e valores da igreja de Roma, gerando duas vertentes: a tradição romano-germânica e a tradição romano-canônica, processo que se estendeu durante os séculos, tendo como fonte, de um lado, o direito processual alemão, ainda rude e elementar, voltado para compor conflitos privados, de outro, o direito canônico, marcado pelo formalismo e pelo ideal do cristianismo sustentado na verdade contrapondo-se as vertentes entre si - o que veio inspirar nosso ordenamento jurídico, ora predominando uma das tendências, ora outra. Os Códigos de 1939 e 1973 comprovam a forte influência romano-canônica, plasmando o processo civil brasileiro. Já o direito de propriedade, registros públicos e a tutela da posse ganham fortes cores germânicas, o que invariavelmente se reflete no processo. Assim, direitos subjetivos individuais predominantemente privados ganham proteção processual num modelo voltado menos à composição do conflito, mais a confirmar a

\footnotetext{
${ }^{2}$ SILVA, Ovídio Araújo Baptista da; GOMES, Fábio Luiz. Teoria Geral do Processo Civil. São Paulo: Editora Revista dos Tribunais, 2006. p. 12/13.

${ }^{3}$ MACEDO, Elaine Harzheim. Jurisdição e processo: crítica histórica e perspectivas para o terceiro milênio. Porto Alegre: Livraria do Advogado Ed., 2005, p. 19.

${ }^{4}$ SILVA, Ovídio A. Baptista da. Processo e ideologia: o paradigma racionalista. Rio de Janeiro: Forense, 2006. p. 131.

${ }^{5}$ Ibidem, p. 145.

6 SILVA, Ovídio A. Baptista da; GOMES, Fábio Luiz. Teoria Geral do Processo Civil. São Paulo: Editora Revista dos Tribunais, 2006. p. 16.
} 
verdade, através da busca da certeza. Choque cultural e de funções que o tempo cuidou de mostrar a (quase) inviável combinação.

A partir daí o procedimento ordinário ou comum, que praticamente rege o processo civil desde então, a separação entre cognição e execução, a esterilidade da sentença condenatória, que reclama nova "ação" para seu cumprimento, bem como a vocação eminentemente ressarcitória, são heranças do modelo clássico de processo de profunda inspiração romanocanônica ${ }^{7}$.

O modelo clássico compreendia o processo de conhecimento, de execução e cautelar, todos voltados para tutela subjetiva individual. 0 individualismo estava plasmado no art. $6^{\circ}$ do Código de 1973, no qual, em linhas gerais, ninguém pode agir em nome de outrem. Diante dessas formas de processo cabe ao lesado a provocação da jurisdição através de uma demanda individual ou de um litisconsórcio ativo. Significa que o modelo foi pensado para atitudes individuais, nunca coletivas. Apenas para registro, porque o tema será retomado adiante, o Código de 2015 mantém a orientação da legitimidade individual em seu art. 18: ninguém poderá pleitear direito alheio em nome próprio, salvo quando autorizado pelo ordenamento jurídico, por uma razão muito clara: o processo civil permanece arraigado em suas raízes clássicas voltado a compor conflitos individuais.

Mostrando o pouco avanço, o legislador reformador inseriu o § único no art. 18 deixando claro que havendo substituição processual o substituído poderá intervir como assistente litisconsorcial. Ele atuará em nome próprio defendendo interesse alheio ${ }^{8}$, mantendo, assim, a orientação da individualidade no processo.

Essa concepção individual, de milenar formação, aumenta sua importância após a Revolução Francesa, quando os respectivos ramos do Direito Privado permaneciam desconhecendo a realidade coletiva. Assim como ocorreu com os direitos constitucionais, decorrentes de valores do liberalismo, a tutela se concentrava sobre a liberdade e o indivíduo, e não sobre a igualdade e sociedade 9 . 0 valor da solidariedade era de todo ignorado. Todavia, após a Segunda Guerra os direitos das sociedades, dos governos, das classes ou grupos sociais passaram a reclamar a devida tutela. Um passo, ainda de dimensão franciscana, foi dado em direção a uma nova era.

\footnotetext{
${ }^{7}$ SILVA, Ovídio A. Baptista da. Jurisdição e execução na tradição romano-canônica. São Paulo: Revista dos Tribunais, 1997, p. 100.

${ }^{8}$ DONIZETTI, Elpídio. Novo Código de Processo Civil Comentado. São Paulo: Atlas, 2015. p. 14.

${ }^{9}$ BONAVIDES, Paulo. Curso de Direito Constitucional. São Paulo: Malheiros, 2011. p. 532.
} 
Da tutela dos direitos sociais aos direitos coletivos foi um segundo passo, ainda que o percurso tenha sido igualmente moroso, permanecendo de um modo geral carente de consolidação em nossos tempos.

Não basta apenas tutelar os direitos coletivos, declarando-os constitucionalmente. Esta conquista foi alcançada pela Constituição de 1988, premissa que não se coloca em discussão. Também se faz imprescindível dotar o sistema de instrumentos aptos à sua exigibilidade e à realização da devida tutela que os concretiza. O sistema jurídico de até então, construído com base no paradigma individual e que gerou profunda aversão pelo papel de grupos sociais, foi posto em dúvida ${ }^{10}$.

Efetivamente, tendo em vista que o sistema processual não foi formatado para os direitos coletivos, tampouco para os interesses transindividuais, sem um titular determinado, não estava o mesmo preparado para essa modalidade de conflitos.

No Brasil, a CLT de 1943, essencialmente voltada para tutelar o direito social ao e do trabalho, fundada na premissa inquestionável de hipossuficiência do trabalhador, dispôs um instrumento (dissídio coletivo) que expandia seus efeitos para uma determinada categoria laboral ou patronal. Depois, em 1946, sobreveio a representação de inconstitucionalidade, com uma perspectiva bem mais abrangente. A ação popular, com legitimidade ativa do cidadão e sentença de efeitos erga omnes, data de 1965. A partir daí o sistema se desenvolveu, chegando a um ápice processual com a Lei da Ação Civil Pública de 1985 e em 1990 com o Código de Defesa do Consumidor, regulamentando ambos os estatutos o regime da coisa julgada nas ações coletivas e contemplando as formas de substituição processual para vencer o impacto da legitimidade ativa. A Lei da Ação Civil Pública e o Código de Defesa do Consumidor fazem as vezes de um Código Coletivo ${ }^{11}$ ou funcionam como minissistema ${ }^{12}$ desse.

Diante do aparecimento e aperfeiçoamento de novos direitos, especialmente coletivos, verificou-se a incompatibilidade dos antigos institutos, tal como legitimidade e coisa julgada. 0 direito deixou de ser exclusivamente individual para se tornar fortemente coletivo. Foi essa a “revolução" constada e destacada por Mauro Capelletti e Bryant Garth ${ }^{13}$ em sua revolucionária obra sobre o acesso à justiça.

\footnotetext{
${ }^{10}$ ALVIM, Arruda. Manual de direito processual civil. São Paulo: RT, 2012. p. 90/91.

${ }^{11} \mathrm{GIDI}$, Antonio. Coisa julgada e litispendência em ações coletivas. São Paulo: Saraiva, 1995. p. 77.

12 GRINOVER, Ada Pellegrini. O projeto de lei brasileira sobre processos coletivos. In: Processo coletivo e outros temas de direito processual. Porto Alegre: Livraria do Advogado, 2012. p. 11.

${ }^{13}$ CAPPELLETTI, Mauro.; GARTH, Bryant. Acesso à justiça. Trad. Ellen Gracie Northfleet. Porto Alegre: Sergio Antonio Fabris, 1988. p.49/50.
} 
Ações relacionadas a questões de consumo, ambiente, religião, planos de saúde e outras de interesse público, deixaram de envolver interesses apenas subjetivos e individuais. 0 processo não mais tutela apenas direitos individuais que atingem uma ou algumas pessoas, mas tutela a coletividade, espraiando-se à própria ordem jurídica, como que se desprendendo dos fatos, mas não sem a eles retornar.

A coletividade estará em juízo representada por um legitimado, ainda que os representados sejam indeterminados e nem sequer saibam da ação, pois não integram a ação diretamente como parte, mas estarão sujeitos ao efeito da sentença nela proferida.

Em virtude dessa modificação da relação processual e de suas consequências, os processos coletivos demandam uma releitura ou compatibilização de antigos institutos processuais, tais como legitimidade, sentença, efeitos e cumprimento da sentença, e principalmente a coisa julgada.

\section{ASPECTOS GERAIS SOBRE A COISA JULGADA CLÁSSICA}

A parte que provoca a jurisdição busca a solução para seu conflito. 0 sistema processual, guardadas suas origens denunciadas no preâmbulo deste artigo, agregou valor entendendo qualificar a composição do conflito como definitiva. Quando uma parte ingressa com uma ação, ela exige que o Estado - que detém o monopólio da jurisdição -, através do Poder Judiciário, pacifique o conflito. A sentença que põe fim ao litígio é a atividade final da jurisdição, na medida em que atende uma das mais tradicionais funções do Poder Judiciário: administrar a justiça do caso concreto. É através da sentença que se pacifica o conflito. Enquanto a sentença não é definitiva, pois sujeita a recurso, não se atingiu a finalidade do processo, que para além da composição da lide contempla julgamento final da res in iudicium deducta ${ }^{14}$. Não sendo mais suscetível de recurso a sentença transita em julgado, tornando-se, por esse motivo, imutável e indiscutível.

De sorte que, após o trânsito em julgado, a sentença de mérito terá o poder de manter o conflito pacificado na mesma medida em que ela possua estabilidade, garantindo a impossibilidade de rediscussão da matéria já decidida, o que o ordenamento jurídico deve contemplar não apenas como mera disposição legal, mas elevar a uma garantia de hierarquia

\footnotetext{
${ }^{14}$ SANTOS, Moacyr Amaral. Primeiras linhas de direito processual civil. Vol. 3. São Paulo: Saraiva, 2011. p. 68.
} 
maior: no caso do Direito brasileiro, garantia constitucional agregada aos direitos individuais e coletivos conforme art. $5^{\circ}$, inciso XXXVI. A qualidade que torna imutável e indiscutível a sentença denomina-se coisa julgada. É a coisa julgada que garante a estabilidade para autoridade plena da sentença.

A justificativa romana para existência da coisa julgada era prática e de utilidade social. Segundo a concepção romana para que houvesse desenvolvimento social seguro e pacífico era necessário imprimir certeza ao gozo dos bens da vida garantindo o resultado do processo ${ }^{15}$. No direito medieval se desenvolveu a ideia de que a coisa julgada era uma presunção de verdade daquilo que o juiz declarava, pois até mesmo uma sentença injusta adquiria autoridade de coisa julgada. Provém daí as máximas de que a coisa julgada faz do branco preto; origina e cria as coisas; transforma o quadrado em redondo; altera os laços de sangue e transforma o falso em verdadeiro $^{16}$. Quando se defende a coisa julgada como uma verdade formal ou como ficção de verdade está se traduzindo a ideia política da coisa julgada ${ }^{17}$.

Nenhum litígio pode ser eterno, sob pena de gerar uma insegurança social. A finitude dos bens da vida alcança também o bem da vida alcançado pela sentença! Além da discussão, também não pode se perpetuar a possibilidade de revisão do que já foi decidido. 0 bem, representado pela prestação jurisdicional perquirida em um devido processo legal, passaria a ser um mal: a eternização dos conflitos. Sob esse enfoque a coisa julgada põe termo ao processo e inviabiliza novos processos, impossibilitando rediscussão sobre a mesma situação, garantindo a paz entre as partes, traduzindo o fundamento de ordem política ${ }^{18}$ da coisa julgada. Conforme salienta Marinoni, um discurso jurídico incapaz de se estabilizar é uma contradição em termos, “já que o poder, fundamento do discurso jurídico, imprescinde do recrudescimento" 19 . Nesse sentido, o instituto da coisa julgada não é essencial ao Direito, mas é conveniente! Sua adoção vem ao encontro de um valor maior que é o da segurança jurídica.

Logo, finalizado o processo, não apenas a sentença não é mais impugnável pelos meios ordinários, como a decisão é vinculante para as partes e se volta essencialmente para eventuais

\footnotetext{
${ }^{15}$ CHIOVENDA, Giuseppe. Instituições de Direito Processual Civil. Trad. J. Guimarães Menegale. Vol. I. São Paulo: Saraiva \& Cia, 1942. p. 512.

${ }^{16}$ COUTURE, Eduardo J. Fundamentos do Direito Processual Civil. São Paulo: RED Livros, 1966. p. 329.

${ }^{17}$ CHIOVENDA, Giuseppe. Instituições de Direito Processual Civil. Trad. J. Guimarães Menegale. Vol. I. São Paulo: Saraiva \& Cia, 1942. p. 514.

18 SANTOS, Moacyr Amaral. Primeiras linhas de direito processual civil. Vol. 3. São Paulo: Saraiva, 2011. p. 71.

${ }^{19}$ MARINONI, Luiz Guilherme. Coisa julgada inconstitucional. São Paulo: Revista dos Tribunais, 2010. p. 57.
} 
futuros juízes: nenhum juiz pode julgar o mesmo objeto em face das mesmas partes. Essa é a essência da coisa julgada para Liebman ${ }^{20}$. 0 fato de os juízes e tribunais de qualquer processo ulterior ficarem vinculados à resolução, não podendo mais rediscutir a matéria já decidida, corrobora o efeito fundamental da coisa julgada ${ }^{21}$.

Dessa forma, a coisa julgada representa a estabilidade da (nova) situação jurídica declarada pela sentença e decorrente da inviabilidade recursal ${ }^{22}$. É considerado elemento essencial ao Estado democrático de Direito garantindo a segurança jurídica, principalmente, (a) por vetar não só ao órgão prolator da sentença, mas a todos os demais, modificá-la, substituí-la ou revogá-la; (b) limitar a possibilidade de impugnar a sentença, enquanto fixa limitados meios recursais; (c) e tornar o julgado vinculante fora do processo em que foi formado ${ }^{23}$.

\subsection{Coisa julgada como direito fundamental}

A coisa julgada, embora seja um instituto próprio do direito processual, está plasmada na Constituição como um direito fundamental, mais precisamente no art. 5, inciso XXXVI. Com base nessa previsão a Constituição Federal atesta a eficácia da coisa julgada como uma garantia inafastável ao Estado Democrático de Direito ${ }^{24}$.

A solução que pacifica um conflito torna-se lei entre as partes e tem sua força reconhecida através da autoridade do Estado que garante a estabilidade dessa decisão. Essa estabilidade que se reflete nas relações sociais, pretéritas e futuras, com a coisa julgada é o corolário do princípio da segurança jurídica transportado para o campo judicial ${ }^{25}$.

A decisão judicial não teria força entre as partes se não carregasse, intrinsecamente, a segurança de que aquela situação não seria mais discutida. Uma solução que não possui estabilidade, que não se torna imutável, é uma opinião ${ }^{26}$, sem qualquer força vinculativa. 0 direito fundamental à tutela adequada, exige que o Estado preste de forma efetiva seu mister

\footnotetext{
${ }^{20}$ LIEBMAN, Enrico Tullio. Manual de Direito Processual Civil. Vol. III. Tocantins: Intelectos, 2003. p. 169.

${ }^{21}$ SCHÖNKE, Adolf. Direito Processual Civil. Atual. Afonso Celso Rezende. Campinas: Romana, 2003. p. 351.

${ }_{22}^{23}$ PORTO, Sérgio Gilberto. Coisa julgada civil. São Paulo: RT, 2011. p. 58.

${ }^{23}$ MITIDIERO, Daniel; ALVARO DE OLIVEIRA, Carlos Alberto. Curso de Processo Civil. Vol. 2. São Paulo: Atlas, 2012. p. 272/273.

${ }^{24}$ PORTO, Sérgio Gilberto. Lições sobre teorias do processo: civil e constitucional. Porto Alegre: Livraria do Advogado, 2013. p. 185.

${ }^{25}$ TAVARES, Andre Ramos. Curso de direito constitucional. São Paulo: Saraiva, 2012. p. 770.

${ }^{26}$ MARINONI, Luiz Guilherme. Coisa julgada inconstitucional. São Paulo: Revista dos Tribunais, 2010. p. 62.
} 
através da jurisdição. Inclui-se nesse direito, sempre que jurídica e politicamente conveniente ao sistema como um todo, a obrigatoriedade da estabilização da tutela para que a matéria não seja rediscutida.

É importante destacar que a coisa julgada não é um princípio, proibindo-se, dessa forma, o seu afastamento através do princípio ou postulado da proporcionalidade, mas é uma regra de conduta a ser respeitada pelos três Poderes e pelos particulares ${ }^{27}$. A estabilidade da decisão se opõe erga omnes.

De outra banda, a garantia da coisa julgada também representa verdadeira blindagem ${ }^{28}$, tornando-a imune a alterações legislativas futuras, pois a própria Constituição garante que a lei não prejudicará a coisa julgada, a exemplo do ato jurídico perfeito e do direito adquirido. Parte da doutrina ${ }^{29}$ entende que a coisa julgada é um caso particular de proteção mais ampla ao direito adquirido.

Não é assim, porém, em todos os ordenamentos jurídicos. A Constituição Portuguesa, por exemplo, não protege o caso julgado de forma explícita. Essa proteção decorre do Estado de Direito democrático, sendo que um caso somente pode ser revisto por via judicial, na base de uma lei geral e abstrata ${ }^{30}$. Da mesma forma, na Alemanha, não há proteção expressa à coisa julgada. O seu fundamento constitucional está ancorado no Estado de Direito ou Verfassungsstaat.

O Estado de Direito é um sobreprincípio que se relaciona com vários outros princípios que incorporam os seus fins ${ }^{31}$. Entre esses princípios correlacionados - e quiçá o de maior relevância - está o da segurança jurídica, traduzida na coisa julgada. Coisa julgada e segurança jurídica estão entrelaçadas numa quase simbiose.

De sorte que a coisa julgada, como produto direto da segurança jurídica, ganhará expressão maior ou menor no ordenamento jurídico na mesma proporção da densidade democrática do Estado que a contempla, até porque a segurança jurídica é implícita ao Estado democrático de Direito.

\footnotetext{
${ }^{27}$ SARLET, Ingo Wolfgang; MARINONI, Luiz Guilherme; MITIDIERO, Daniel. Curso de Direito Constitucional. São Paulo: RT, 2012. p. 672/673.

${ }_{28}^{28}$ PORTO, Sérgio Gilberto. Coisa julgada civil. São Paulo: RT, 2006. p. 58/59.

${ }^{29}$ BASTOS, Celso Ribeiro; MARTINS, Ives Gandra. Comentários à Constituição do Brasil. Vol. 2. São Paulo: Saraiva, 2001. p. 218.

${ }^{30}$ CANOTILHO, José Joaquim Gomes; MOREIRA, Vital. Constituição da Republica Portuguesa Anotada. Coimbra: Coimbra editores, 1993. p. 800.

${ }^{31}$ MARINONI, Luiz Guilherme. Coisa julgada inconstitucional. São Paulo: Revista dos Tribunais, 2010. p. 65.
} 
Contudo, é importante ressaltar que nem sempre a estabilidade e a imutabilidade de uma decisão representarão a justiça no caso concreto, devendo ser levado em consideração outros princípios e garantias constitucionais. 0 próprio constitucional assegura a estabilidade do conflito pacificado com a garantia da coisa julgada, mas o limite de sua incidência está na lei, que não só não afirma que toda decisão com trânsito em julgado constitui coisa julgada ${ }^{32}$, como também prevê ação própria para a sua desconstituição.

De qualquer forma, a coisa julgada é uma garantia constitucional-processual que assegura a ideia e o exercício da cidadania processual ${ }^{33}$.

\subsection{Coisa julgada formal e material}

No processo da Idade Média contemplavam-se as sentenças definitivas, que decidiam a questão principal, e as chamadas sentenças interlocutórias que decidiam questões processuais incidentes, surgindo a necessidade de distinguir coisa julgada material de coisa julgada formal. Os romanos não conheciam a distinção entre a coisa julgada formal e a coisa julgada material ${ }^{34}$ A coisa julgada formal é a imutabilidade da sentença em virtude da preclusão das impugnações e dos recursos. Impede as partes de discutirem e o juiz de decidir questões já decididas naquele feito $^{35}$, revestindo-se de característica endoprocessual. Redunda na imutabilidade da sentença, como ato processual, dentro do processo ${ }^{36}$.

É a impossibilidade de discussão, no mesmo processo e pelas mesmas partes, diante da ausência de possibilidade de impugnação da decisão, seja pelo esgotamento de recursos, ou pelo não exercício destes, tornando a sentença um "fenômeno" imodificável ${ }^{37}$.

Configurava-se, até a entrada em vigor da Lei n. 11.232/05, como um ato estatal de término da jurisdição no processo, passando, já sob a vigência do Código de 1973, pós reforma, e conforme Código de 2015, como ato de término da jurisdição apenas na hipótese de extinção do processo (respectivamente, artigos 267 do CPC/73 e 485 do CPC/2015) ou, nos casos de decisão de mérito, do ato estatal de jurisdição que resolve o conflito na sua fase de

\footnotetext{
32 BASTOS, Celso Ribeiro; MARTINS, Ives Gandra. Comentários à Constituição do Brasil. Vol. 2. São Paulo: Saraiva, 2001. p. 219/220.

${ }_{33}^{33}$ PORTO, Sérgio Gilberto. Coisa julgada civil. São Paulo: RT, 2011. p. 62.

${ }^{34}$ ALVIM, José Eduardo Carreira. Teoria Geral do Processo. Rio de Janeiro: Forense, 2011. p. 264.

${ }^{35}$ Idem, p. 265.

${ }^{36}$ SANTOS, Moacyr Amaral. Primeiras linhas de direito processual civil. Vol. 3. São Paulo: Saraiva, 1998. p. 43.

37 PORTO, Sérgio, Gilberto. Coisa julgada civil. São Paulo: RT, 2011. p. 68
} 
conhecimento (respectivamente, artigos 269 do CPC/73 e 487 do CPC/2015). Inexistindo recurso contra sentença ou acórdão, que reexaminou a sentença que resolveu o conflito ou aquela que confirmou a extinção do processo, despiciendo, para este momento lógico do processo, se houve o julgamento do mérito da lide ou não, opera-se a coisa julgada formal ${ }^{38}$.

Enquanto a coisa julgada formal tem aspecto eminentemente processual, não comprometida com o direito material subjacente, a coisa julgada material ou substancial é a aquela que decide o mérito da questão, adentrando nos meandros da lide, do conflito. 0 comando que emerge da sentença adquire autoridade de coisa julgada impedindo que a relação de direito material, entre as mesmas partes, seja reexaminada ou novamente decidida, pelo mesmo ou outro juiz ou tribunal ${ }^{39}$. Como se pode verificar a coisa julgada material é extraprocessual, pois seus efeitos repercutem para fora do processo ${ }^{40}$.

A imutabilidade do conteúdo, através da sentença que tem força de lei entre as partes, adquire com a coisa julgada material autoridade de coisa julgada ${ }^{41}$, fortalece-se, afirma-se no sistema como enunciado jurídico.

Para que se configure a coisa julgada material é necessário seu pressuposto lógico antecedente, a coisa julgada formal, embora tudo aconteça num único momento processual. Julgado o mérito e seguindo-se a preclusão para interposição de recursos ou impugnações, independentemente da atuação do juiz, consagra-se a coisa julgada formal, à qual se segue, no âmbito lógico, a coisa julgada material. Somente depois disso, é formada a coisa julgada material. Dessa forma, a coisa julgada formal é pressuposto da coisa julgada material ${ }^{42}$.

Muito embora a distinção entre a coisa julgada formal e a material esteja consagrada na lei e na doutrina pátria, há posições ${ }^{43}$ que não reconhecem na coisa julgada formal o instituto, para quem, assim como para os romanos, a coisa julgada somente se verifica quando a res é iudicata, ou seja, quando existe exame de mérito. A coisa julgada formal não seria, para esse segmento, senão uma forma de preclusão. De acordo com esse entendimento o correto seria

\footnotetext{
${ }^{38}$ SANTOS, Ernani Fidélis dos. Manual de Direito Processual Civil. Vol. 1. São Paulo: Saraiva, 2006. p. 612.

39 SANTOS, Moacyr Amaral. Primeiras linhas de direito processual civil. Vol. 3. São Paulo: Saraiva, 1998. p. 44.

${ }^{40}$ MARINONI, Luiz Guilherme; ARENHART, Sérgio Cruz. Manual do Processo de Conhecimento. São Paulo: RT, 2005. p. 611.

${ }^{41}$ ALVIM, José Eduardo Carreira. Teoria Geral do Processo. Rio de Janeiro: Forense, 2011. p. 265.

42 No mesmo sentido ALVIM, José Eduardo Carreira. Teoria Geral do Processo. Rio de Janeiro: Forense, 2011. p. 265 e CINTRA, Antonio Carlos de Araújo; GRINOVER, Ada Pellegrini; DINAMARCO, Cândido Rangel. Teoria Geral do Processo. São Paulo: Malheiros, 2011. p. 333.

${ }^{43}$ Nesse sentido SILVA, Ovídio Araújo Baptista da; GOMES, Fábio Luiz. Teoria Geral do Processo Civil. São Paulo: RT, 2011. p. 291; e MITIDIERO, Daniel; ALVARO DE OLIVEIRA, Carlos Alberto. Curso de Processo Civil. Vol. 2. São Paulo: Atlas, 2012. p. 273/274.
} 
falar em coisa julgada (material) e preclusão (formal). 0 tema, por si só, permitiria desdobramentos que os limites deste trabalho não comportam.

\subsection{Função negativa e positiva da coisa julgada}

A coisa julgada possui uma dupla função ou duplo efeito, o negativo e o positivo. A função negativa é um impedimento, uma verdadeira proibição ${ }^{44}$, de que não se possa mais examinar o que foi decidido em qualquer processo futuro. Já a função positiva é aquela que exige que seja levado em consideração o que já fora decidido, vinculando o juiz ${ }^{45}$ ou tribunal, projetando-se em lides futuras. Ainda que o pedido seja diverso não pode ser desprezado o que já foi julgado, devendo ser levado em conta no processo seguinte.

Exemplifica-se. Em uma ação envolvendo um acidente de trânsito restou comprovada a responsabilidade do réu em virtude de sua imprudência. Em sentença foi condenado a pagar ao autor os danos materiais requeridos por esse em sua inicial. Ocorre que além de danos materiais, o autor também sofreu danos morais não requeridos na primeira inicial. Tendo em vista a comprovada responsabilidade do réu pelo acidente, já prolatada na ação de dano material, não há razão para se averiguar novamente de quem fora a culpa. Tendo transitado em julgado a ação que reconhece a responsabilidade do réu pelo acidente, todos os atos decorrentes desse seu ato serão indenizáveis, desde que demonstrado o dano alegado.

Outro exemplo é o caso de êxito do impetrante em ação de mandado de segurança, reconhecendo-se na sentença que $\mathrm{o}$ ato da autoridade foi ilegal ou abusivo. Em processo posterior, o impetrante requer a indenização pelos danos que sofreu enquanto submetido ao ato de autoridade já reconhecido pelo Judiciário indevido. Nesse processo ressarcitório, movido contra o Estado, este só poderá se defender ou alegando inexistência de dano ou que o valor pretendido é elevado e desproporcional ao dano causado. O que não mais está em discussão é a tese de que o ato da autoridade estatal é legal e não abusivo.

Com base no primeiro exemplo não pode o réu ingressar com uma ação indenizatória visando à condenação do autor pelos seus danos, haja vista que a responsabilidade exclusiva do réu já foi reconhecida (função negativa), nem tampouco pode ser julgada improcedente a demanda ressarcitória por ausência de responsabilidade (função positiva).

\footnotetext{
${ }^{44}$ PORTO, Sérgio Gilberto. Coisa julgada civil. São Paulo: RT, 2006. p. 66.

${ }^{45}$ MITIDIERO, Daniel; ALVARO DE OLIVEIRA, Carlos Alberto. Curso de Processo Civil. Vol. 2. São Paulo: Atlas, 2012. p. 289.
} 
Vale o mesmo raciocínio, guardadas as proporções de cada pleito, para o exemplo do mandado de segurança.

\subsection{Limites subjetivos e objetivos da coisa julgada}

O limite subjetivo da coisa julgada diz respeito a quem a sentença passa em julgado, que pessoas estão sujeitas à indiscutibilidade e à imutabilidade. 0 art. 506 do CPC/2015 dispõe: “a sentença faz coisa julgada às partes entre as quais é dada, não prejudicando terceiros”, distanciando-se do art. 472 do CPC/73, quando a sentença trânsita em julgado não beneficiava nem prejudicava terceiros. A alteração legislativa culmina por admitir que uma sentença trânsita em julgado possa, sim, alcançar sua autoridade como comando estatal terceiros, se for para beneficiá-los. Não pode é prejudicar quem não participou do processo e não teve como deduzir suas defesas. Por certo que o terceiro beneficiado não está jungido à decisão, podendo até renunciar ao seu direito, mas dela poderá se valer para buscar seus eventuais direitos. A coisa julgada não pode ser deduzida contra terceiros em respeito ao princípio do contraditório ${ }^{46}$, mas nada impede que seja manejada pelos terceiros beneficiados. O novo comando legal fortalece a decisão judicial e certamente produzirá significativas discussões, especialmente nas ações reconhecidas como repetitivas ou de massa.

A tradição processual brasileira admite, como exceção ${ }^{47}$, que a indiscutibilidade e imutabilidade da sentença estenda-se a terceiros, mesmo que não tenham intervindo no processo. São os casos de assistência, conforme dispõe o art. 42, $\S 3^{\circ}$, do CPC/73, quando a assistência tiver por fundamento sucessão de partes, seja por força de ato inter vivo ou causa mortis, tradição essa mantida no CPC/2015, conforme art. 109, § $3^{\circ}$ : “estendem-se os efeitos da sentença proferida entre as partes originárias ao adquirente ou cessionário".

Situação distinta - e isso sempre se admitiu no sistema processual pátrio -, diz com a possibilidade de os efeitos da sentença atingir terceiros. Os direitos e as realidades fáticas não se divorciam. Por esse motivo, os terceiros que mantêm situações jurídicas conexas à situação jurídica julgada pela sentença são atingidos pela sua eficácia, mas jamais pela coisa julgada ${ }^{48}$,

\footnotetext{
${ }^{46}$ PAIS DE AMARAL, Jorge Augusto. Direito Processual Civil. Coimbra: Almedina, 2001. p. 331.

${ }^{47}$ TESHEINER, J. M. R. Eficácia da sentença e coisa julgada no processo civil. São Paulo: RT, 2001. p. 81.

${ }^{48}$ MITIDIERO, Daniel; ALVARO DE OLIVEIRA, Carlos Alberto. Curso de Processo Civil. Vol. 2. São Paulo: Atlas, 2012. p. 287.
} 
situação que o novo Código de Processo Civil não altera, até porque o fundamento não está no processo, mas nas relações de direito material. ${ }^{49}$

Imagine-se, por exemplo, um sublocatário que possui contrato apenas com o locatário. Vindo esse último a sofrer uma ação de despejo pelo locador, ainda que o sublocatário não seja parte na ação de despejo, terá também que desocupar o imóvel. É o chamado efeito reflexo ${ }^{50}$ da coisa julgada. Por óbvio, que o terceiro prejudicado pela eficácia da sentença, poderá insurgirse contra ela, em processo futuro, tendo em vista que não foi atingido pela coisa julgada ${ }^{51}$, alegando, por exemplo, eventual dano a ser ressarcido porque não seria caso de rescisão contratual.

Se por um lado o limite subjetivo é aquele que define quem ficará sujeito a coisa julgada, o limite objetivo determina que parte da sentença faz coisa julgada. O CPC de 2015, ainda que mantendo alguns traços da legislação pretérita, trouxe importantes modificações no trato dos limites objetivos.

O grande busílis é, afinal, saber quais questões que não podem mais ser debatidas entre as partes. O CPC/ 73, em seu artigo 468, dispõe que "a sentença, que julgar total ou parcialmente a lide, tem força de lei nos limites da lide e das questões decididas." A partir daí ressalta que o conceito de lide utilizado pelo legislador é o carneluttiano. ${ }^{52}$ Com efeito, o CPC

\footnotetext{
${ }^{49}$ Conforme elucida Elpídio Donizetti o STJ já explicou os limites subjetivos no caso concreto na decisão que segue: PROCESSO CIVIL. RECURSO ESPECIAL. DEVEDOR SOLIDÁRIO NÃO INTEGRANTE DO POLO PASSIVO DA ACCÃO DE COBRANCCA. ARRESTO. IMPOSSIBILIDADE.

1. 0 art. 275 do Código Civil - que prevê a solidariedade passiva - é norma de direito material, restringindo-se sua aplicação ao momento de formação do processo cognitivo, quando então o credor pode incluir no polo passivo da demanda todos, alguns ou um específico devedor; sendo certo que a sentença somente terá eficácia em relação aos demandados, não alcançando aqueles que não participaram da relação jurídica processual, nos termos do art. 472 do Código de Processo Civil.

2. A responsabilidade solidária precisa ser declarada em processo de conhecimento, sob pena de tornar-se impossível a execução do devedor solidário, ressalvados os casos previstos no art. 592 do mesmo diploma processual. Desse modo, o arresto cautelar que atinge bem de terceiro é passível de impugnação mediante a propositura dos embargos de terceiro (art. 1.046 do CPC).

3. No caso, não tendo a recorrente figurado no polo passivo da ação de cobrança nem estando incluída no rol do referido art. 592 do CPC, não podem os seus bens ser atingidos pelo arresto determinado em medida cautelar incidente à ação de cobrança, tampouco por futura execução. Aplicação analógica da Súmula 268 do STJ.

4. Recurso especial provido.

(REsp 1423083/SP, Rel. Ministro LUIS FELIPE SALOMÃO, QUARTA TURMA, julgado em 06/05/2014, DJe 13/05/2014).

DONIZETTI, Elpídio. Novo Código de Processo Civil Comentado. São Paulo: Atlas, 2015. p. 385.

${ }^{50}$ LIEBMAN, Enrico Tullio. Manual de Direito Processual Civil. Vol. III. Tocantins: Intelectos, 2003. p. 180.

${ }^{51}$ CINTRA, Antonio Carlos de Araújo; GRINOVER, Ada Pellegrini; DINAMARCO, Cândido Rangel. Teoria Geral do Processo. São Paulo: Malheiros, 2011. p. 337.

${ }^{52}$ SILVA, Ovídio A. Baptista da. Sentença e coisa julgada. Rio de Janeiro: Forense, 2003. p. 104.
} 
de 2015 não fala mais em sentença nem tampouco em lide. Ao invés da palavra sentença agora o legislador usou decisão, enquanto lide foi transmudada em questão principal.

A ideia de que não faz coisa julgada os motivos que determinaram o alcance da parte dispositiva da sentença e a verdade dos fatos utilizada como fundamento, plasmadas no art. 469 do CPC/73, permanece hígida no art. 504 do CPC de 2015.

As questões que dizem respeito ao mérito da causa, mas não expressamente decididas não restam acobertadas pela coisa julgada, mas preclusas quando invocadas com o objetivo de enfraquecer a coisa julgada. ${ }^{53}$ Nesse sentido já se manifestou o STJ. ${ }^{54}$

A coisa julgada incide sobre o dispositivo da sentença (art. 489, III e 504, ambos CPC de 2015), então as questões devidamente alegadas pelas partes durante a ação (inicial, contestação

53 MARINONI, Luiz Guilherme; ARENHART, Sérgio Cruz; MITIDIERO, Daniel. Novo código de processo civil
comentado. São Paulo: RT, 2015. p. 516.
54 PROCESSUAL CIVIL. ART. 535 DO CPC. ALEGAÇÕES GENÉRICAS. SÚMULA 284/STF. PRECLUSÃO PRO
JUDICATO. EFICÁCIA PRECLUSIVA DA COISA JULGADA.
1. É impossível conhecer-se do recurso especial pela alegada violação ao artigo 535 do CPC nos casos em
que a argüição é genérica, por incidir a Súmula 284/STF, assim redigida: "É inadmissível o recurso
extraordinário, quando a deficiência na fundamentação não permitir a exata compreensão da controvérsia".

2. Não pode prevalecer, em face do óbice da preclusão pro judicato, a decisão do magistrado de primeira instância que tenha por fim retratar decisão interlocutória objeto de agravo de instrumento não conhecido pelo Tribunal aq quem.

3. O acórdão proferido pela instância de segundo grau, ao não conhecer do mérito do agravo de instrumento pela inobservância do disposto no art. 526 do CPC, trouxe como efeito a manutenção da decisão agravada, impedindo que fosse reaberto o prazo para retratação do juiz de piso. Solução em contrário, importaria em supressão de instância.

4. 0 art. 468 do Código de Processo Civil explicita que a sentença tem força de lei, ou seja, faz coisa julgada, nos limites da lide e das questões decididas, o que impede a propositura de ação idêntica, com as mesmas partes, causa de pedir e pedido.

5. Já o art. 474 do CPC dispõe sobre a impossibilidade de se rediscutir não apenas as questões que tenham sido explicitamente decididas no dispositivo, porquanto expressamente alegadas pelas partes, mas também aquelas que poderiam ser alegadas e não o foram.

6. Da interpretação desses dispositivos, extrai-se o óbice para a propositura de ação idêntica, rediscussão de pontos já decididos na sentença e alegação de fatos novos não aduzidos por desídia da parte.

7. Malgrado constar do dispositivo da sentença a determinação para que, após o trânsito em julgado, os depósitos fossem convertidos em renda da União, o reconhecimento da decadência com a conseqüente determinação de levantamento dos depósitos pela empresa recorrida não ofende a coisa julgada.

8. Em face da decadência ter-se operado no curso da lide, seria desarrazoado exigir que a parte suscitasse esse fato extintivo em momento anterior. Além disso, essa tese não foi discutida na ação de conhecimento, consubstanciando outra causa de pedir sujeita a nova coisa julgada.

9. Recurso especial conhecido em parte e improvido.

(REsp 861.270/PR, Rel. Ministro CASTRO MEIRA, SEGUNDA TURMA, julgado em 05/10/2006, DJ 16/10/2006, p. 358). 
e reconvenção) e que forem objeto da parte dispositiva da sentença, ficarão acobertadas pelos limites objetivos da coisa julgada. ${ }^{55}$

Porém a alteração legislativa, no âmbito da coisa julgada, mais profunda está na possibilidade de que questão prejudicial resolvida expressa e incidentemente no processo também poderá sofrer os efeitos da coisa julgada (art. 503, § $1^{\circ}, \mathrm{CPC} / 15$ ). Fica estendida à questão prejudicial a coisa julgada ${ }^{56}$. Essa alteração já recebeu críticas por parte da doutrina ${ }^{57}$.

Não obstante, a questão prejudicial é aquela subordinada que influencia no julgamento. Exemplo clássico é a busca de reserva de parte de um quinhão hereditário, sem uma sentença que reconheça a filiação. Caso julgado improcedente o pedido, por entender o juiz que o autor não era filho do de cujus, a questão da herança fazia coisa julgada, porém a relação de filiação não integrava a coisa julgada. Para que a filiação fosse revestida pelo manto da coisa julgada seria necessário o ajuizamento de uma ação declaratório incidental.

Deparando-se, no processo, o juiz com questão prejudicial ele a decidirá antes de resolver o mérito ${ }^{58}$.

Com efeito, de acordo com o novo CPC se o juiz tiver competência para resolver a questão prejudicial (art. 503, § $1^{\circ}$, III), não havendo restrições probatórias ou limitação a profundidade da cognição (art. 503, § $2^{\circ}$ ), tendo ocorrido contraditório prévio e efetivo, sem revelia (art. 503, § $\left.1^{\circ}, \mathrm{II}\right)$ e dessa resolução depender o julgamento do mérito (art. 503, $\left.\S 1^{\circ}, \mathrm{I}\right)$, pode essa fazer coisa julgada.

É importante destacar que a formação da coisa julgada com relação à questão prejudicial independe de prévio pedido das partes, tornando, por esse motivo, o modelo da coisa julgada adotado pelo novo CPC de formação cooperativa ${ }^{59}$.

Dessa forma, com base no novo CPC, as questões expressamente decididas pela sentença no dispositivo, seja por indicação das partes ou, agora autorizada (art. 503, §§ $1^{\circ}$ e $2^{\circ}$ ), por indicação do juiz farão coisa julgada estabelecendo novos limites objetivos.

\footnotetext{
${ }^{55}$ MARINONI, Luiz Guilherme; ARENHART, Sérgio Cruz; MITIDIERO, Daniel. Novo curso de processo civil. Vol. 2. São Paulo: RT, 2015. p. 632.

${ }^{56}$ TESHEINER, J. M. R; THAMAY, Rennan Faria Krüger. Teoria Geral do Processo: em conformidade com o novo CPC. Rio de Janeiro: Forense, 2015 p.209.

${ }^{57}$ WAMBIER, Luiz Rodrigues; TALAMINE, Eduardo. Curso avançado de processo civil. Vol. 1. São Paulo: RT, 2015. p. 704.

${ }^{58}$ NEVES, Daniel Amorim Assumpção. Manual de direito processual civil. Rio de Janeiro: Forense, 2015, p. 630.

${ }^{59}$ MARINONI, Luiz Guilherme; ARENHART, Sérgio Cruz; MITIDIERO, Daniel. Novo curso de processo civil. Vol. 2. São Paulo: RT, 2015. p. 634.
} 


\section{A CONCEPÇÃO CLÁSSICA DA COISA JULGADA E O FENÔMENO DAS AÇÕES COLETIVA: DISTANCIAMENTO E APROXIMAÇÕES}

A concepção clássica, aqui exposta em apertada síntese, sobre a coisa julgada foi desenvolvida com base em direitos e conflitos individuais subjetivos. Contudo, quando essas concepções clássicas são transportadas para outra realidade, como a do processo coletivo lato sensu $^{60}$, precisam de um novo olhar, um olhar despregado da racionalidade do conflito individual subjetivo, o que forçosamente implicará uma distinção da coisa julgada no âmbito clássico voltado para os direitos individuais daquela produzida no processo coletivo. Por envolver um somatório de interesses e não apenas um interesse subjetivo individual ou pluri-individual bem definido, com repercussão social da sentença, por vezes a uma comunidade de interessados indefinida, o que desde o primeiro movimento processual nesse sentido (Ação Popular, Lei $4.717 / 65$, art. 18) levou o legislador a tratar de forma distinta a coisa julgada coletiva, cuidando de sua repercussão, tanto no que diz com os limites subjetivos e os limites objetivos.

A partir do desenvolvimento da legislação que regula as ações coletivas o dogma da coisa julgada vem sendo repensado, em especial a Lei da Ação Civil Pública e o Código de Defesa do Consumidor.

\subsection{Direitos coletivos e defesa coletiva de direitos}

Conforme visto alhures os direitos e as garantias foram construídos calcados em valores do liberalismo, na liberdade e no indivíduo, e não na igualdade e sociedade.

É imperioso lembrar que não apenas os direitos, mas também as garantias constitucionais tiveram de se amoldar a nova demanda de direitos sem uma correspondência subjetiva individualista. Após a Segunda Guerra se fez necessário a ampliação do raio de segurança de

\footnotetext{
${ }^{60}$ Para este trabalho, tem-se a compreensão de processo coletivo como espaço para a composição de conflitos coletivos, utilizando-se sua classificação em três subgrupos: conflito coletivo com base em interesses difusos, conflito coletivo stricto sensu, quando os direitos coletivos e transindividuais pertencem a uma classe ou categoria definida e conflito repetitivo com base em direitos individuais homogêneos.
} 
formas funcionais institucionalizadas ${ }^{61}$, invariavelmente ligadas ao exercício constitucional das atividades dos poderes públicos. A supremacia do pensamento individual que caracterizou o Estado liberal dá lugar à segurança das instituições e direitos fundamentais que representam e dão sustentação ao Estado social. Em oposição ao interesse individual ganha frente o interesse público e a relevância social ${ }^{62}$.

Com o desenvolvimento dos interesses de grupo - metaindividuais ${ }^{63}$ ou transindividuais ${ }^{64}$ e não mais individuais, emergem os chamados direitos de terceira dimensão e conforme Ingo Wolfgang Sarlet ${ }^{65}$ a nota distintiva desses direitos reside basicamente na sua titularidade coletiva, muitas vezes indefinida e indeterminável. A tônica, aqui, fica por conta da exigibilidade da tutela coletiva: quem se legitima para.

Importa destacar, como lembra Gilmar Mendes, Inocêncio Coelho e Paulo Branco, que a doutrina lusitana já atribuía uma dimensão subjetiva e objetiva aos direitos fundamentais, estabelecendo uma duplicidade de dimensão como direito subjetivo e objetivo, individual e comunitário $^{66}$.

Significa que as garantias fundamentais individuais, em verdade, possuíam uma dimensão subjetiva e outra objetiva. Cumpre salientar que o fato do direito ser coletivo prescinde da aquiescência de todos.

Não se pode, pois, confundir a defesa coletiva de direitos com a defesa de direitos coletivos. Os direitos coletivos são subjetivamente transindividuais e materialmente indivisíveis $^{67}$, estão no art. 81 , § único, I e II, do CDC . A indivisibilidade significa que a ofensa do bem repercute em toda coletividade ${ }^{68}$. De outra banda, a defesa coletiva de direitos é aquela voltada para os direitos individuais homogêneos (art. 81, § único, III, do CDC), que, ao fim e ao

\footnotetext{
${ }^{61}$ BONAVIDES, Paulo. Curso de Direito Constitucional. São Paulo: Malheiros, 2011. 534.

${ }^{62}$ DONIZETTI, Elpídio; CERQUEIRA, Marcelo Malheiros. Curso de processo coletivo. São Paulo: Atlas, 2010. P. 17.

${ }^{63}$ TAVARES, Andre Ramos. Curso de direito constitucional. São Paulo: Saraiva, 2012. p. 891.

${ }^{64}$ ZAVASCKI, Teori Albino. Processo coletivo: tutela de direitos coletivos e tutela coletiva de direitos. São Paulo: Revista dos Tribunais, 2011. p. 34

${ }_{65}$ SARLET, Ingo Wolfgang. A eficácia dos direitos fundamentais. Porto Alegre: Livraria do Advogado, 2008, p. 56.

${ }^{66}$ MENDES, Gilmar Ferreira; COELHO, Inocêncio Mártires; BRANCO, Paulo Gustavo Gonet. Curso de Direito Constitucional. São Paulo: Saraiva, 2008. p. 1372.

${ }^{67}$ ZAVASCKI, Teori Albino. Processo coletivo: tutela de direitos coletivos e tutela coletiva de direitos. São Paulo: Revista dos Tribunais, 2011. p. 34.

${ }^{68}$ DONIZETTI, Elpídio; CERQUEIRA, Marcelo Malheiros. Curso de processo coletivo. São Paulo: Atlas, 2010. p. 45.
} 
cabo, representam um conjunto de direitos subjetivos individuais ligados entre si, por afinidade e semelhança, que permite a defesa coletivas de todos eles ${ }^{69}$.

Os direitos transindividuais não têm titulares individuais certos, pois pertencem não a indivíduos, mas a grupos de pessoas, a coletividade, enquanto os individuais homogêneos têm titulares individuais juridicamente certos ${ }^{70}$.

\subsection{Coisa julgada nas ações coletivas}

Diferentemente das ações individuais que possuem um sujeito determinado, nas ações coletivas o titular será um sujeito indeterminado. A partir dessa questão de legitimidade já se verifica, num primeiro momento, a evidente incompatibilidade dos limites subjetivos da coisa julgada da concepção clássica (direitos individuais), que fica somente entre as partes, enquanto nas ações de direitos coletivos ela será inter partes, ultra partes ou erga omnes. Sendo assim, a decisão proferida atingirá a esfera jurídica de todos os membros da coletividade ou grupo ${ }^{71}$.

Com o desenvolvimento da tutela dos direitos coletivos através da ação civil pública, mandado de segurança coletivo, ação popular e, no âmbito da constitucionalidade das leis e atos normativos, ação declaratória de constitucionalidade, ação direita de inconstitucionalidade e arguição de descumprimento de preceito fundamental, entre outras, a coisa julgada passou a ter seus efeitos potencializados a terceiros que não participaram diretamente do processo, modificando a ideia do artigo 472 do CPC de 1973, representante maior da concepção clássica e regra contemporânea ao desenvolvimento daquelas ações coletivas ou com repercussão coletiva.

No direito estadunidense a solução encontrada para os efeitos da coisa julgada contra terceiros, nas ações coletivas (class action), foi a adequação da representação ${ }^{72}$. Independentemente do resultado do feito, havendo a adequacy of representation (idoneidade do

\footnotetext{
${ }^{69}$ ZAVASCKI, Teori Albino. Processo coletivo: tutela de direitos coletivos e tutela coletiva de direitos. São Paulo: Revista dos Tribunais, 2011. p. 34.

${ }^{70}$ ZAVASCKI, Teori Albino. Processo coletivo: tutela de direitos coletivos e tutela coletiva de direitos. São Paulo: Revista dos Tribunais, 2011. p. 37.

${ }_{71}^{71} \mathrm{GIDI}$, Antonio. Coisa julgada e litispendência em ações coletivas. São Paulo: Saraiva, 1995. p. 59.

72 Conforme lembra Antonio Gidi a "representação adequada", no direito americano, é analisada caso a caso pelo magistrado. GIDI, Antonio. Coisa julgada e litispendência em ações coletivas. São Paulo: Saraiva, 1995. p. 63.
} 
portar judicial) ${ }^{73}$, todos serão atingidos pela coisa julgada, porque se "representados", não podem ser considerados terceiros ${ }^{74}$.

Num primeiro momento, com a Lei da Ação Popular, mais especificamente em seu artigo 18, a coisa julgada estabelecida foi o reconhecimento de sua eficácia erga omnes. Seguindo o mesmo caminho veio a Lei da Ação Civil Pública e por último o Código de Defesa do Consumidor, em seu artigo 102, aplicável à Ação Civil Pública, artigo 21.

Esse microssistema partiu do pressuposto de que os autores da ação são os substitutos processuais e que muitas vezes os substituídos sequer sabem da ação. Para que estes sujeitos não sofram os efeitos de uma ação improcedente, sem saber que estavam sendo representados em juízo, esses não serão atingidos pela auctoritas rei judicata.

A coisa julgada coletiva deve ser visualizada a partir da análise de três elementos: a) limites subjetivos - quem se submete à coisa julgada b) limites objetivos - o que se submete aos seus efeitos; c) o modo de produção - como ela se forma ${ }^{75}$.

Nos limites subjetivos, a coisa julgada pode ser inter partes, ou seja, entre as partes que figuraram no processo; ultra partes, que atinge determinados terceiros que não participaram (caso de sucessão no processo individual ou de substituição processual no processo coletivo); e erga omnes que atinge a todos, tenham ou não participado do processo.

Nos direitos ou interesses difusos a coisa julgada é erga omnes. A satisfação do interesse de um dos membros significa a satisfação do interesse de todos, enquanto a negação de um importa para todos, exceto no caso de insuficiência de $\operatorname{provas}^{76}$.

Não é por outra razão que o artigo 103 do CDC estabelece para esses casos que a coisa julgada, diferentemente das ações individuais, não se sujeita apenas às partes do processo em

\footnotetext{
${ }^{73}$ MANCUSO, Rodolfo de Camargo. Jurisdição coletiva e coisa julgada. São Paulo: RT, 2012. p. 37. ${ }_{75}^{74} \mathrm{GIDI}$, Antonio. Coisa julgada e litispendência em ações coletivas. São Paulo: Saraiva, 1995. p. 62.

${ }^{75}$ DIDIER JR, Fredie; ZANETI JR, Hermes. Curso de Direito Processual Civil. Vol. 4. Salvador: JusPodivmp, 2010. p. 363/364.

${ }^{76}$ GRINOVER, Ada Pellegrini; WATANABE, Kazuo; MULLENIX, Linda. Os processos coletivos nos países da Civil Law e Common Law. São Paulo: RT, 2011. p.237.
} 
que a sentença foi proferida, mas se for julgada procedente ela beneficia a todos os titulares do direito, com o estabelecimento de limites subjetivos erga omnes ${ }^{77}$.

A seu turno os limites objetivos representam a autoridade da norma jurídica individualizada, concretizada na sentença. Tradicionalmente, a coisa julgada no ordenamento jurídico pátrio está restrita ao dispositivo (art. 504 do CPC/2015 e art. 469 do CPC/73) e, em certa medida, às questões prejudiciais (art. 503, § $1^{\circ}$ do CPC/2015 e art. 470 do CPC/73). É o thema decidendum do objeto litigioso que limita objetivamente a coisa julgada ${ }^{78}$.

No que tange ao modo de produção da coisa julgada há três tipos. Coisa julgada pro et contra, que se forma independentemente do resultado. A secundum eventum litis, que só é produzida quando a demanda for julgada procedente e a secundum eventum probationis que só existe com o esgotamento das provas. Se for julgada improcedente por falta de provas não produz coisa julgada. Essas duas últimas formas estão dispostas no microssistema da tutela coletiva, no art. 103 do CDC.

Através da redação empregada pelo legislador é possível verificar um tratamento bem diferenciado para a coisa julgada no âmbito coletivo. Está cristalina a intenção do legislador em privilegiar a efetividade e adequação da tutela sobre a segurança jurídica ${ }^{79}$.

A coisa julgada pro et contra é própria das class actions e utilizada pela maioria dos ordenamentos jurídicos. Em verdade, no nosso sistema coletivo, é possível defender que a coisa julgada também é pro et contra. A coisa julgada sempre é formada independentemente do resultado da demanda. Na verdade, o que muda com o evento da lide não é a formação ou a ausência de formação da coisa julgada, mas quem será atingido. Em virtude disso, o que é secundum eventum litis não é a formação da coisa julgada, mas a sua extensão (ultra partes ou erga omnes) refletindo na esfera de terceiros prejudicados pela conduta ilícita na ação coletiva ${ }^{80}$.

Significa que independentemente do resultado da ação a via coletiva estará preclusa, impossibilitando o grupo de pleitear o mesmo direito, seja ele difuso, coletivo ou individual

\footnotetext{
77 MITIDIERO, Daniel; ALVARO DE OLIVEIRA, Carlos Alberto. Curso de Processo Civil. Vol. 2. São Paulo: Atlas, 2012. p. 291.

${ }^{78}$ MANCUSO, Rodolfo de Camargo. Jurisdição coletiva e coisa julgada. São Paulo: RT, 2012. p. 261.

79 DONIZETTI, Elpídio; CERQUEIRA, Marcelo Malheiros. Curso de processo coletivo. São Paulo: Atlas, 2010. p. 360.

${ }^{80} \mathrm{GIDI}$, Antonio. Coisa Julgada e litispendência em ações coletivas. São Paulo: Saraiva, 1995. p.73.
} 
homogêneo $^{81}$. A autoridade da sentença poderá alcançar a todos, em benefício ou em prejuízo, salvo em caso de improcedência por falta de provas, ou ainda ser utilizada em favor de membros da classe, sem possibilidade de prejudicar suas pretensões individuais ${ }^{82}$.

Por sua vez a coisa julgada secundum eventum litis, conforme os $\S \S 1^{\circ}$ e $2^{\circ}$ do art. 103 do CDC, nos direitos difusos, coletivos e individuais homogêneos, em suma, só poderá beneficiar os direitos individuais dos membros do grupo.

Envolvendo direitos ou interesses difusos, por exemplo, tendo o pedido sido julgado improcedente por insuficiência de provas, há quem defenda ${ }^{83}$ que não haverá coisa julgada material, mas apenas formal. Qualquer legitimado pode voltar a juízo inclusive o antigo autor. Para isso basta que a ação tenha por fundamento prova nova. A insuficiência probatória deve ser entendida como a não produção de prova já existente à época da instrução e também daquelas que só vieram e existir posteriormente ${ }^{84}$. Não há necessidade de a decisão ser clara, ou seja, explicitar que o processo está sendo julgado improcedente em virtude da falta de provas, basta decorrer do conteúdo da decisão ${ }^{85}$.

De qualquer sorte, com ou sem insuficiência de provas, a sentença não produzirá efeitos erga omnes se o pedido for julgado improcedente. Os particulares não serão atingidos pela coisa julgada, mas apenas as partes que integraram o processo coletivo. Sendo assim, os particulares poderão exercer suas ações individuais ${ }^{86}$. Também no Código Modelo, especificamente no art. 194, conforme lembra Roberto Berizonce ${ }^{87}$, os processos envolvendo interesses difusos a sentença terá eficácia erga omnes, salvo se for improcedente por ausência de provas, podendo a questão ser reproposta em outro processo por outro legitimado.

${ }^{81} \mathrm{GIDI}$, Antonio. Rumo ao código de processo civil coletivo: a codificação das ações coletivas no Brasil. Rio de Janeiro: GZ, 2008. p. 289.

${ }^{82}$ CINTRA, Antonio Carlos de Araújo; GRINOVER, Ada Pellegrini; DINAMARCO, Cândido Rangel. Teoria Geral do Processo. São Paulo: Malheiros, 2011. p. 337.

83 LEONEL, Ricardo de Barros. Manual do processo coletivo. São Paulo: RT, 2013. p. 295. FERREIRA, Rony. Coisa julgada nas ações coletivas. Porto Alegre: Safe, 2004. p. 111.

${ }^{84}$ DONIZETTI, Elpídio; CERQUEIRA, Marcelo Malheiros. Curso de processo coletivo. São Paulo: Atlas, 2010. p. 359.

${ }_{85}$ DIDIER JR, Fredie; ZANETI JR, Hermes. Curso de Direito Processual Civil. Vol. 4. Salvador: JusPodivmp, 2010. p. 367.

${ }^{86}$ MITIDIERO, Daniel; ALVARO DE OLIVEIRA, Carlos Alberto. Curso de Processo Civil. Vol. 2. São Paulo: Atlas, 2012. p. 291.

${ }^{87}$ BERIZONCE, Roberto Omar. Bases para actualizar el Codigo modelo Processual Civil para Iberoamerica. In: Processo coletivo e outros temas de direito processual. Porto Alegre: Livraria do Advogado, 2012.p. 544. 
Da mesma forma, a coisa julgada nos direitos coletivos secundum eventum litis não poderá prejudicar os interesses e direitos individuais de integrantes da classe, podendo apenas beneficiá-los, em caso de procedência. As regras dos direitos e interesses difusos servem aqui, todavia, a coisa julgada é ultra partes, pois limitada ao grupo, categoria ou classe, salvo na hipótese de improcedência por insuficiência de $\operatorname{provas}^{88}$.

Seguindo o mesmo raciocínio, nas ações para defesa de direito individuais homogêneos, a coisa julgada é secundum eventum litis, ao contrário, por exemplo, do sistema anglo-americano, em que a coisa julgada existe na procedência ou improcedência da ação, tanto para os representantes quanto para os representados ${ }^{89}$. No sistema da common law é utilizado o critério do opt in (no qual o membro do grupo devidamente notificado ingressa voluntariamente na ação, tornando-se parte) e opt out (o membro da classe requer sua exclusão da ação, na sua inércia será considerado parte e sofrerá os efeitos da coisa julgada $)^{90}$, lembrando um pouco a regra utilizada no processo individual que o direito brasileiro oferta ao sucessor da parte por ato inter vivos, conforme art. 109 , §§§ $1^{\circ}, 2^{\circ}$ e $3^{\circ}$, do CPC/2015.

$\mathrm{Na}$ forma secundum eventum litis, se o pedido for julgado improcedente, a coisa julgada se forma para os autores coletivos ${ }^{91}$. Contudo, individualmente os sujeitos que não tiveram suas ações suspensas podem ingressar sem ofensa à coisa julgada coletiva ${ }^{92}$. Dessa forma, envolvendo direitos individuais homogêneos, se a ação for procedente ou improcedente, haverá sempre coisa julgada material para os legitimados coletivos enquanto que os indivíduos só serão beneficiados e não prejudicados ${ }^{93}$.

Com efeito, é importante destacar que a coisa julgada nas ações coletivas do direito brasileiro não segue a regra secundum eventum litis. Tendo em vista que a coisa em julgado sempre se formará, pro et contra, o que diferirá é o rol de pessoas atingidas por ela, restando secundum eventum litis não a formação da coisa julgada, mas sua extensão erga omnes ou ultra

\footnotetext{
${ }^{88}$ LEONEL, Ricardo de Barros. Manual do processo coletivo. São Paulo: RT, 2013. p. 296.

89 LEAL, Márcio Flávio Mafra. Ações coletivas: História, teoria e prática. Porto Alegre: Fabris, 1998. p. 208.

90 GRINOVER, Ada Pellegrini; WATANABE, Kazuo; MULLENIX, Linda. Os processos coletivos nos países da Civil Law e Common Law. São Paulo: RT, 2011. p. 239.

${ }^{91}$ GIDI, Antonio. Coisa Julgada e litispendência em ações coletivas. São Paulo: Saraiva, 1995. p.73.

92 GRINOVER, Ada Pellegrini. O processo em evolução. Rio de Janeiro: Forense. 1996. p. 119.

93 LEONEL, Ricardo de Barros. Manual do processo coletivo. São Paulo: RT, 2013. p. 297.
} 
partes à esfera jurídica individual de terceiros prejudicados pela conduta considerada ilícita na ação coletiva. ${ }^{94}$

Existe ainda a coisa julgada secundum eventum probationis. Alguns países da América Latina preveem, que a prova nova, desde que apta a modificar o resultado da ação, pode ensejar a propositura de uma nova ação. Seria uma autorização ao iudicium rescisorium. Da mesma maneira como acontece nos casos de exame de DNA, nas demandas individuais, uma prova nova poderia gerar uma ação revisional coletiva. Nesse caso a coisa julgada incidiria exclusivamente nas provas produzidas no processo ${ }^{95}$. Essa possibilidade tem sido muito debatida no âmbito coletivo, nos direitos difusos, em especial relacionados ao meio ambiente ${ }^{96}$.

Diante desse quadro, se a demanda for julgada improcedente por insuficiência ou ausência de provas, a coisa julgada não se forma contra ninguém, inclusive contra o próprio autor (art. 18 da Lei $n^{\circ} 4.717 / 64$, art. 16 da Lei 7.347/85, art. $4^{\circ}$ da Lei 7.853/89, artigo 103, I e II do $C D C)$.

Defende-se a opção pela coisa julgada secundum eventum probationis pelo interesse, em algumas matérias, em ponderar topicamente o valor justiça em detrimento do valor segurança ${ }^{97}$.

Existem duas razões para que a formação da coisa julgada seja secundum eventum probationis. A primeira consiste na necessidade de se evitar possível colusão entre o substituto e o réu, prejudicando dessa forma todo o grupo titular do direito, a ensejar todos os cuidados para que o grupo não sofra as consequências por erros ou falhas processuais ${ }^{98}$. A segunda razão está relacionada à ideia de justiça. O legislador quis garantir que o mérito fosse decidido de maneira adequada $^{99}$, privilegiando o interesse coletivo e a justiça do caso à segurança jurídica da indiscutibilidade do que fora decidido. O fundamento não surpreende, pois é o mesmo que sustenta a adoção, pelo ordenamento jurídico, da ação rescisória: entre o valor da segurança

\footnotetext{
${ }^{94} \mathrm{GIDI}$, Antonio. Coisa Julgada e litispendência em ações coletivas. São Paulo: Saraiva, 1995. p.73/74.

${ }^{95}$ GRINOVER, Ada Pellegrini; WATANABE, Kazuo; MULLENIX, Linda. Os processos coletivos nos países da Civil Law e Common Law. São Paulo: RT, 2011. p. 242.

${ }_{96}$ DIDIER JR, Fredie; ZANETI JR, Hermes. Curso de Direito Processual Civil. Vol. 4. Salvador: JusPodivmp, 2010. p. 366.

97 Nesse sentido DIDIER JR, Fredie; ZANETI JR, Hermes. Curso de Direito Processual Civil. Vol. 4. Salvador: JusPodivmp, 2010. p. 367; e DONIZETTI, Elpídio; CERQUEIRA, Marcelo Malheiros. Curso de processo coletivo. São Paulo: Atlas, 2010. p. 360.

${ }_{98}$ DONIZETTI, Elpídio; CERQUEIRA, Marcelo Malheiros. Curso de processo coletivo. São Paulo: Atlas, 2010. p. 360.

${ }_{99}$ Ibidem, idem.
} 
jurídica e a hipótese de consagrar-se uma forte injustiça com base em determinados e taxados vícios ou erros, o sistema opta por rediscutir o caso julgado. Não se olvide que a previsão é para os casos de improcedência quando ausentes provas dos fatos alegados pela parte autora, limitando, portanto, a exceção à coisa julgada.

De tudo que até aqui se abordou, forçoso concluir que relativamente à sentença de procedência, a coisa julgada se inspira na tradição clássica do instituto, com o destaque para beneficiar terceiros, transportando-se o comando do julgamento para os eventuais processos individuais, que a aproveitam. É o chamado transporte in utilibus usado para beneficiar os litigantes em ações individuais. Tendo em vista os princípios da isonomia e economia processual não seria crível inadmitir o aproveitamento da sentença coletiva o que resultaria, ao fim e ao cabo, em absoluta inutilidade, com ofensa ao princípio da utilidade que ilumina o processo civil.

\section{CONTRIBUTO DO NOVO CPC E OS CONFLITOS REPETITIVOS}

O texto do novo Código de Processo Civil, Lei n. 13.105/2015, não se mostrou imune aos novos conflitos e à dimensão dos direitos e interesses coletivos. Embora com função precípua de regular o processo subjetivo individual, ficando para leis extravagantes a regulação das ações coletivas $^{100}$, conforme tradição das últimas três décadas, o estatuto adentrou nesta seara, com fito de regulamentar as ações que dizem com o chamado conflito repetitivo ${ }^{101}$, podendo ser consideradas como ações pseudoindividuais, pois embora movidas, no mais das vezes individualmente, tem por fundamento controvérsia de direito que diz com a mesma questão de fato, fenômeno que gera a repetitividade e consequente numerosidade de processos, pondo em risco a garantia constitucional da isonomia e a própria segurança jurídica, em relação aos jurisdicionados, e inviabilizando a atuação jurisdicional efetiva e expedita do Poder Judiciário, tanto no primeiro grau como na jurisdição recursal.

São inúmeros os dispositivos e institutos criados ou revisitados para superar o impasse da numerosidade dos processos, crise que atingiu em cheio o Código de 1973, provocando as

\footnotetext{
${ }^{100}$ No Congresso Nacional tramitam há vários anos projetos que ora priorizam a reforma da Lei da Ação Civil Pública, ora propõem a instituição de um Código de Processo Coletivo.

${ }_{101}$ Remete-se o leitor para MACEDO, Elaine Harzheim; MACEDO, Fernanda dos Santos. 0 direito processual civil e a pós-modernidade. Revista de Processo, vol. 204, São Paulo: Editora Revista dos Tribunais, fevereiro de 2012, p. 351-367.
} 
reformas que se processaram principalmente ao longo da primeira década dos anos dois mil ${ }^{102}$. Entre as principais diretrizes do novo Código para enfrentamento do fenômeno, pode-se citar: a) reestruturação das funções dos tribunais, arts. 926 a 928; b) incidente de assunção de competência, art. 947; c) incidente de resolução de demandas repetitivas, arts. 976 a 987; d) improcedência liminar do pedido no âmbito da jurisdição de primeiro grau, art. 332; e) decisões monocráticas nos tribunais, art. 932, incisos IV e V; $f$ ) técnica de julgamento por amostragem nos recursos repetitivos junto ao STF e ao STJ, arts. 1.036 a 1.041. Agregam-se a esse conjunto de normas, os institutos constitucionais das decisões erga omnes proferidas em sede de processo objetivo (ADI, ADC, ADPF); a repercussão geral do recurso extraordinário (art. 102, inciso III, § $3^{\circ}$, da CF); e a súmula vinculante (art. 103-A, da CF), formando um complexo de decisões judiciais, respaldadas pelos tribunais superiores e qualificadas pelo efeito vinculante, que passam a configurar uma verdadeira função normativa do Poder Judiciário, permeando tais institutos e ganhando reforço com a ação de reclamação, arts. 988 a 993.

No que tange a coisa julgada, ainda que não haja tratamento específico para decisões proferidas em sede de conflitos repetitivos, o art. 506 inova em relação ao Código de 1973, dispondo: "a sentença faz coisa julgada às partes entre as quais é dada, não prejudicando terceiros". Diferentemente do Código revogado, em seu art. 472, não mais contempla a expressão “[...] não beneficiando, nem prejudicando terceiros", o que implica uma transposição dos limites subjetivos, permitindo, portanto, que a sentença venha a beneficiar terceiros.

Tal dispositivo tem ou pode ter destinatários certos: terceiros que não integram a(s) ação(s) repetitiva(s) que foi ou foram julgadas com efeito vinculante, por um dos mecanismos que a lei processual introduz neste novo paradigma de processo.

Por óbvio que não se discute que a sentença pode produzir efeitos sobre terceiros, mas não é esse o ponto do debate e sim até que ponto a sentença pode ou não, pelas vias comuns, ser rediscutida por terceiros, alcançando a indiscutibilidade e imutabilidade também aqueles que não integraram o processo em que foi ela proferida. 0 art. 506 do Código não diz respeito aos eventuais efeitos (declaratórios, constitutivos, condenatórios, executivos, mandamentais) da

${ }^{102}$ MACEDO, Elaine Harzheim; VIAFORE, Daniele. A decisão monocrática e a numerosidade no Processo Civil brasileiro. Porto Alegre: Livraria do Advogado Editora, 2015, p. 119-126. 
sentença, mas sim à sua (in)discutibilidade e (i)mutabilidade ${ }^{103}$. Em apertada síntese, o art. 506 do novo CPC permite que a sentença trânsita julgada venha a beneficiar terceiros. Quais seriam? No que diz com os sucessores, seja por ato inter vivos ou causa mortis, dispensam esse dispositivo porque contam com regra expressa conforme antes já mencionado (art. 109, § $3^{\circ}$ ). Remanescem, pois, os terceiros que se encontram na condição de titulares de direitos coletivos ou subjetivos homogêneos, mas que não integraram o processo provocado na forma individual, mas julgado na forma de um dos mecanismos processuais e constitucionais acima arrolados.

De sorte que três são as conclusões:

$1^{\text {a) }}$ A decisão, assim proferida, há de valer para todos, estendendo-se o leque subjetivo de sua indiscutibilidade e imutabilidade, se beneficiar o terceiro substituído, aqui utilizada a adjetivação metaforicamente, refletindo-se no caso para os futuros processos.

$2^{\text {a) }}$ Os processos idênticos que restaram estancados para ter curso o mecanismo específico de coletivização dos processos e suas respectivas partes - autor e réu -, se submetem à indiscutibilidade e imutabilidade da decisão, tenha essa vindo em seu benefício ou não, isso porque a hipótese conta com regras específicas, a exemplo, art. 987, $\S 2^{\circ}$, ao tratar do I.R.D.R, e o art. 1.039 e seu $\S$ único, regulando o julgamento dos recursos extraordinários e especiais repetitivos.

$3^{\text {a) }}$ Por força do art. 506, se a decisão trânsita em julgado vier em detrimento aos direitos ou interesses do terceiro, estará livre o caminho para a proposição de sua ação individual. É certo que o art. 332 do CPC de 2015 permite que o juiz liminarmente julgue improcedente 0 pedido que se voltar contra decisão proferida em sede de processos repetitivos, mas o fundamento é o art. 487, inciso I, e não a ofensa ao instituto da coisa julgada, art. 485, inciso V, sem embargo de eventualmente, vir o pleito a ser recebido e ter andamento normal, conforme dispõe o $\S 4^{\circ}$ do art. 332.

Pode-se concluir, no caso dos conflitos repetitivos, que a (nova) lei processual aproximase quanto ao instituto da coisa julgada do microssistema do processo coletivo, propondo uma ponte de permanente intercâmbio entre o individual e o coletivo, o que poderá contribuir para uma maior racionalidade do sistema e funcionalidade do Poder Judiciário.

103 TESHEINER, José Maria Rosa; THAMAY, Rennan Faria Krüger. Teoria Geral do Processo: em conformidade com o novo CPC. Rio de Janeiro: Forense, 2015, p. 207-208. 


\section{CONCLUSÃO}

Com o desenvolvimento de novas modalidades de defesa de direitos, bem como a existência de direitos de terceira dimensão verificou-se a incompatibilidade dos antigos institutos, tal como legitimidade e coisa julgada. 0 direito deixou de ser tutelado para 0 indivíduo para ganhar uma acepção coletiva.

Ações envolvendo coletividades de consumidores, cidadãos, contribuintes e outros grupos que a sociedade contemporânea possibilita, deixaram de envolver interesses apenas individuais subjetivos. O processo não pode mais voltar-se a proteger exclusivamente o indivíduo, mas também a coletividade. Sendo assim, de um lado, a coletividade estará em juízo representada por um legitimado, ainda que os representados sequer saibam da ação, pois não integram a relação processual diretamente como parte, mas estarão sujeitos ao efeito da sentença nela proferida; de outro, ações pseudoindividuais promovidas por autores individuais que versem sobre direitos e interesses que atingem uma coletividade, o que não pode ser negligenciado pela lei processual, clamando por regras próprias.

O fenômeno da numerosidade do processo e as novas dimensões de direitos sociais e coletivos propõem um novo discurso, especialmente quanto ao instituto da coisa julgada, que os estudiosos do processo devem atentar. Institutos tradicionais, como a Ação Civil Pública e as ações coletivas do Código de Defesa do Consumidor, senão os primeiros mas certamente os mais importantes estatutos processuais a enfrentarem o tema, devem dialogar com o novo Código de Processo Civil que pelo menos na medida dos direitos individuais homogêneos, sem descartar outros direitos ou interesses coletivos que porventura ensejem ações individuais, investe no instituto, criando regras que assegurem a sua principal função, plasmada pela Constituição republicana, que é a segurança jurídica. Não se está a defender que o sistema está pronto e acabado, mas cuja necessidade noticiada num passado mais remoto agora ganha relevo à consagração do Estado social democrático de Direito, isso é indiscutível e daí sua importância no sistema processual. 


\section{REFERÊNCIAS}

ALVIM, Arruda. Manual de direito processual civil. São Paulo: RT, 2012.

ALVIM, José Eduardo Carreira. Teoria Geral do Processo. Rio de Janeiro: Forense, 2011.

BARBOSA MOREIRA. José Carlos. Eficácia da sentença e autoridade da coisa julgada. In: Temas de direito processual. São Paulo: Saraiva, 1984.

BASTOS, Celso Ribeiro; MARTINS, Ives Gandra. Comentários à Constituição do Brasil. Vol. 2. São Paulo: Saraiva, 2001.

BERIZONCE, Roberto Omar. Bases para actualizar el Codigo modelo Processual Civil para Iberoamerica. In: Processo coletivo e outros temas de direito processual. Porto Alegre: Livraria do Advogado, 2012.

BONAVIDES, Paulo. Curso de Direito Constitucional. São Paulo: Malheiros, 2011.

CANOTILHO, José Joaquim Gomes; MOREIRA, Vital. Constituição da Republica

Portuguesa Anotada. Coimbra: Coimbra editores, 1993.

CAPPELLETTI, Mauro.; GARTH, Bryant. Acesso à justiça. Trad. Ellen Gracie Northfleet. Porto Alegre: Sergio Antonio Fabris, 1988.

CHIOVENDA, Giuseppe. Instituições de Direito Processual Civil. Trad. J. Guimarães Menegale. Vol. I. São Paulo: Saraiva \& Cia, 1942.

CINTRA, Antonio Carlos de Araújo; GRINOVER, Ada Pellegrini; DINAMARCO, Cândido Rangel. Teoria Geral do Processo. São Paulo: Malheiros, 2011.

COUTURE, Eduardo J. Fundamentos do Direito Processual Civil. São Paulo: RED Livros, 1966.

CUNHA JÚNIOR, Dirley da. Curso de Direito Constitucional. Salvador: JusPodivm. 2011.

DAVID, René. Os grandes sistemas do Direito contemporâneo. São Paulo: Martins Fontes, 2002.

DIDIER JR, Fredie; ZANETI JR, Hermes. Curso de Direito Processual Civil. Vol. 4. Salvador: JusPodivmp, 2010.

DONIZETTI, Elpídio. Novo Código de Processo Civil Comentado. São Paulo: Atlas, 2015. 
Paulo: Atlas, 2010.

; CERQUEIRA, Marcelo Malheiros. Curso de processo coletivo. São

FERREIRA, Rony. Coisa julgada nas ações coletivas. Porto Alegre: Safe, 2004.

GIDI, Antonio. Coisa julgada e litispendência em ações coletivas. São Paulo: Saraiva, 1995.

GIDI, Antonio. Rumo ao código de processo civil coletivo: a codificação das ações coletivas no Brasil. Rio de Janeiro: GZ, 2008.

GRINOVER, Ada Pellegrini. O processo em evolução. Rio de Janeiro: Forense. 1996.

GRINOVER, Ada Pellegrini. O projeto de lei brasileira sobre processos coletivos. In: Processo coletivo e outros temas de direito processual. Porto Alegre: Livraria do Advogado, 2012.

GRINOVER, Ada Pellegrini; WATANABE, Kazuo; MULLENIX, Linda. Os processos coletivos nos países da Civil Law e Common Law. São Paulo: RT, 2011.

LEAL, Márcio Flávio Mafra. Ações coletivas: História, teoria e prática. Porto Alegre: Fabris, 1998.

LEONEL, Ricardo de Barros. Manual do processo coletivo. São Paulo: RT, 2013.

LIEBMAN, Enrico Tullio. Manual de Direito Processual Civil. Vol. III. Tocantins: Intelectos, 2003.

MACEDO, Elaine Harzheim. Jurisdição e processo: crítica histórica e perspectivas para o terceiro milênio. Porto Alegre: Livraria do Advogado Ed., 2005.

; MACEDO, Fernanda dos Santos. O direito processual civil e a pós-modernidade. Revista de Processo, vol. 204, São Paulo: Editora Revista dos Tribunais, fevereiro de 2012, p. 351-367.

; VIAFORE, Daniele. A decisão monocrática e a numerosidade no Processo Civil brasileiro. Porto Alegre: Livraria do Advogado Editora, 2015.

MANCUSO, Rodolfo de Camargo. Jurisdição coletiva e coisa julgada. São Paulo: RT, 2012.

MARINONI, Luiz Guilherme. Coisa julgada inconstitucional. São Paulo: Revista dos Tribunais, 2010. ; ARENHART, Sérgio Cruz; MITIDIERO, Daniel. Novo código de processo civil comentado. São Paulo: RT, 2015. 
curso de processo civil. Vol. 2. São Paulo: RT, 2015. 2005. ; ARENHART, Sérgio Cruz. Manual do Processo de Conhecimento. São Paulo: RT, MAZZILLI, Hugo Nigro. A defesa dos interesses difusos em juízo. São Paulo: Saraiva, 2000.

MENDES, Gilmar Ferreira; COELHO, Inocêncio Mártires; BRANCO, Paulo Gustavo Gonet. Curso de Direito Constitucional. São Paulo: Saraiva, 2008.

MITIDIERO, Daniel; ALVARO DE OlIVEIRA, Carlos Alberto. Curso de Processo Civil. Vol. 2. São Paulo: Atlas, 2012.

NEVES, Daniel Amorim Assumpção. Manual de direito processual civil. Rio de Janeiro: Forense, 2015.

PAIS DE AMARAL, Jorge Augusto. Direito Processual Civil. Coimbra: Almedina, 2001. PORTO, Sérgio Gilberto. Coisa julgada civil. São Paulo: RT, 2006.

SANTOS, Ernani Fidélis dos. Manual de Direito Processual Civil. Vol. 1. São Paulo: Saraiva, 2006.

SANTOS, Moacyr Amaral. Primeiras linhas de direito processual civil. Vol. 3. São Paulo: Saraiva, 1998.

SARLET, Ingo Wolfgang. A eficácia dos direitos fundamentais. Porto Alegre: Livraria do Advogado, 2008.

; MARINONI, Luiz Guilherme; MITIDIERO, Daniel. Curso de Direito Constitucional. São Paulo: RT, 2012.

SCHÖNKE, Adolf. Direito Processual Civil. Atual. Afonso Celso Rezende. Campinas: Romana, 2003.

SILVA, Ovídio A. Baptista da. Processo e ideologia: o paradigma racionalista. Rio de Janeiro: Forense, 2006.

. Sentença e coisa julgada. Rio de Janeiro: Forense, 2003.

. Jurisdição e execução na tradição romano-canônica. São Paulo: Revista dos

Tribunais, 1997.

; GOMES, Fábio Luiz. Teoria Geral do Processo Civil. São Paulo: RT, 2011. 
TAVARES, Andre Ramos. Curso de direito constitucional. São Paulo: Saraiva, 2012.

TESHEINER, J. M. R. Eficácia da sentença e coisa julgada no processo civil. São Paulo: RT, 2001.

; THAMAY, Rennan Faria Krüger. Teoria Geral do Processo: em conformidade com o novo CPC. Rio de Janeiro: Forense, 2015.

WAMBIER, Luiz Rodrigues; TALAMINE, Eduardo. Curso avançado de processo civil. Vol. 1. São Paulo: RT, 2015.

ZAVASCKI, Teori Albino. Processo coletivo: tutela de direitos coletivos e tutela coletiva de direitos. São Paulo: Revista dos Tribunais, 2011.

Recebido em: 26.08.2015 / Revisões em: 16.09.2015 / Aprovado em: 21.09.2015 